\title{
5 \\ MENGEMBANGKAN SDM PERPUSTAKAAN \\ DALAM RANGKA MENUJU WORLD \\ CLASS UNIVERSITY
}

\author{
Wiji Suwarno \\ IAIN Salatiga, Jawa Tengah, Indonesia \\ wiji.suwarno@gmail.com
}

\begin{abstract}
The library as a meeting area between the writer and the readers by materials as it's media, where it is becomes an important meaning for civilization if it was interpreted as a lifelong education by users. This article touches some aspects of the library in the context of human resources development which is intended as a step towards realizing the ideals of the library are included in the category of world class university. Human Resources Development is in the form of curiousity, intuition, humor and services, need to be there and be maximized so that librarians were able to escort the library to refer to the activities of the world class university, such as: Research and development college, Publications, Citation / webometrics, Networks, Quality of the information and knowledge resource.
\end{abstract}

Keywords: Library resources, World Class

\begin{abstract}
Abstrak
Perpustakaan sebagai tempat bertemunya penulisa dan pembaca dengan media bahan pustaka yang dikelolanya, menjadi arti penting bagi peradaban ketika dimaknai sebagai tempat pendidikan sepanjang hayat. Tulisan menyentuh aspek perpustakaan dalam konteks pengembangan SDMnya
\end{abstract}


yang ditujukan sebagai langkah mewujudkan cita-cita menuju perpustakaan yang masuk dalam kategori world class university. Pengembangan SDM ini yang berupa curiousity, intuition, humor dan services, perlu ada dan dimaksimalkan agar pustakawan mampu mengawal perpustakaan untuk mengacu pada kegiatan-kegiatan kelas dunis, seperti: Research and development college, Publication, Citation/ webometrics, Networks, Quality of the information and knowledge resources.

Kata Kunci: Perpustakaan, Pengembangan, World Class

\section{A. Pendahuluan}

World Class University (WCU) menjadi istilah yang membumi pada beberapa kurun waktu terakhir ini. Perguruan Tinggi (PT) menjadi pionir terdepan yang mengambil istilah ini untuk diimplementasikan. Tentu saja dengan berbagai resiko kritik masyarakat terhadap institusi. Bisa jadi perguruan tinggi ini dinilai masyarakat sebagai aksi untuk meningkatkan kualitas, bisa juga berefek pada promosi yang mempropaganda pikiran masyarakat untuk memihak dan mengantarkan putra-putrinya masuk kuliah di perguruan tinggi tersebut. Namun lebih dari itu ada satu kesan positif dari WCU ini adalah untuk membulatkan kualitas PT sehingga secara akademis mampu memberikan nilai optimal yang bisa disandingkan dengan PT lainnya di dunia internasional. World Class Univeristy (WCU) sebenarnya dimulai sejak Departemen pendidikan Nasional (Diknas) membentuk Tim Gugus Tugas Penetapan 10 Perguruan Tinggi (PT) yang dipersiapkan untuk menjadi universitas kelas dunia. Tidak lama kemudian Diknas kembali memberikan peluang bagi 50 PT untuk tujuan yang sama. PT itu terdiri dari 27 PT negeri dan 23 PT swasta. ${ }^{1}$

Upaya memprovokasi kepada pihak Diknas, menghasilkan 50 PT untuk melakukan dialog dengan sejumlah rekanan mulai dari

1 Azyumardi Azra, "World Class University," Republika. 20 April, 2006. 
tingkat ASEAN hingga ke tingkat dunia, juga menjanjikan akan memberikan fasilitas untuk mengikuti akreditasi internasional.

Boleh jadi PT berlomba menyajikan penampilanpenampilan kualitas terbaiknya, tetapi perlu diingat bahwa ada komponen yang vital yang membantu sebutan kualitas tersebut. Tanpa lembaga yang satu ini, kualitas PT patut di pertanyakan. Komponen yang tidak kalah digadangkan itu adalah perpustakaan. Mengapa demikkian? Bisa ditegaskan disini bahwa institusi yang bernama perpustakaan ini merupakan centre of knowledge nya perguruan tinggi. Peran perpustakaan di perguruan tinggi belum tergantikan jika pendekatannya adalah rekam-saji karya ilmiah, yang dulu sempat dikenal bahwa perpustakaan sebagai pengelola informasi dan pengetahuan. Perpustakaan era kini dituntut memahami konsumennya (costumer), memahami bagaiamana membuat manajemen yang baik, melayani dengan ketulusan, dan berpihak pada pemustaka. ${ }^{2}$

Menuju universitas kelas dunia (WCU) bukanlah suatu hal yang mudah, tetapi juga bukan sesuatu yang tidak mungkin. Seperti yang dikatakan Altbach (2003), "For most countries, even large and relatively wealthy ones, only one or two world-class universities are possible or even desirable. For many countries, a world-class university is beyond the ability of the nation to support." ${ }^{3}$ Untuk sebagian Negara, terutama negara yang besar dan kaya, mewujudkan univeristas kelas dunia ini bukan sesuatu yang mustahil, tetapi ini pun hanya satu atau dua universitas saja yang dipacu. dan untuk sebagian besar Negara, sebuah universitas kelas dunia merupakan impian. Masalahnya adalah pada kekuatan mana atau distingsi apa suatu PT itu masuk ke wilayan WCU ini. Karenanya pada dasarnya konsep WCU mencerminkan norma dan nilai lembaga-lembaga

2 Richard Rubin, Foundations of Library and Information Science, Fourth edition (Chicago: ALA Neal-Schuman, an imprint of the American Library Association, 2016), 156.

${ }^{3}$ Philip Altbach, "The Costs and Benefits of World-Class Universities," International Higher Education, no. 33 (2015): 3, http://ejournals.bc.edu/ojs/ index.php/ihe/article/viewFile/7381/6578. 
akademis dunia yang memiliki orientasi dominan pada penelitian, terutama Amerika Serikat dan Eropah Barat. ${ }^{4}$

Hayward menambahkan untuk menuju WCU bukan sekedar infrastruktur semata, tetapi lebih penting dari itu adalah mentalitas untuk melakukan perubahan. Di negara-negara berkembang ditemukan bahwa, "The major obstacles are not money but... mentality." Menuju WCU diperlukan perubahan yang mendasar, yaitu perubahan mental, yaitu menciptakan suatu keinginan untuk merubah universitasnya menjadi berkelas dunia, sehingga hal inilah yang membutuhkan dukungan seluruh civitas akademika. "Change will not take place without the general recognition within the university community that it is necessary. Part of the process of strategic planning is to get people to recognize the need for change."

\section{B. Pembahasan}

\section{Pengembangan Sumber Daya manusia sebagai langkah awal}

Perpustakaan dalam era perkembangan sekarang ini memerlukan tenaga-tenaga yang mumpuni di bidang perpustakaan yang mampu beradaptasi terhadap kebutuhan baik secara teknis maupun pemikiran pengembangan ke depan. Pengembangan dalam hal ini diarahkan pada perbaikan, peningkatan, membuat sesuatu inovasi baru dari program kegiatan atau rencana yang sudah ada sebelumnya. Kata kunci pengembangan itu adalah ada sesuatu yang berbeda dari kondisi sebelumnya.

Demikian halnya dengan sumber daya manusianya yang sudah selayaknya mengikuti perkembangan teknologi informasi yang berjalan. Sumber daya manusia di perpustakaan tidak

4 Enny Haryanti, "Strategi Pengembangan Kelembagaan Perguruan Tinggi Menuju World Classs University,” n.d., 1, accessed May 12, 2016.

5 Fred M. Hayward, "Strategic Planning for Higher Education in Developing Countries: Challenges and Lessons.," Planning for Higher Education 36, no. 3 (2008): 7.

${ }^{6}$ Altbach, "The Costs and Benefits of World-Class Universities." 
lain adalah pustakawan itu sendiri. Orientasi akhirnya adalah pada pemberian pelayanan yang sebaik mungkin dengan modal kompetensi yang baik dan bila perlu memiliki keunikan yang berbeda dengan orang kebanyakan.

Memberikan pelayanan yang baik kepada pemustaka pada era keterbukaan informasi ini menjadi prioritas utama bagi perpustakaan dan pustakawan ${ }^{7}$, atau dengan kata lain adalah user oriented. Pengembangan yang dilihat oleh Kline adalah pada wilayah:

a. Curiosity atau keingintahuan. Wilayah keingintahuan ini perlu dikembangkan sebagai awal dari pengembangan diri secara individu. Jika rasa curiosity ini sudah tertanam pada diri pustakawan, maka untuk belajar terhadap sesuatu yang memungkinkan, niscaya untuk terus belajar.

b. Intuition. Intuisi ini merupakan kemampuan yang dimiliki manusia untuk menganalisa sesuatu yang akan dikerjakan atau dilaksanakan, karena dengan memakai intuisi maka pekerjaan yang akan dilakukan telah diketahui bentuk dan hasilnya. Maka pengembangan dari sisi ini menurut Kline penting untuk dilakukan.

c. Humor atau humor. Humor dalam interaksi sosial sebagai media mendekatkan dan mengakrabkan satu orang dengan lainnya. Humor memberikan kesan kelegawaan dan kerendahan hati untuk bisa saling menerima. Humor merupakan perisai dari kegelisahan dan keterpurukan perasaan. Hal ini perlu dikembangkan sebagai upaya menjaga kepribadian yang selalu ceria dan terbuka terhadap kritik positif dari orang lain.

Sevices atau pelayanan. Pelayanan merupakan sikap memberikan bantuan atau pertolongan kepada orang lain sehingga orang lain merasa bahagia karena dalam pemenuhan kebutuhannya dipermudah. ${ }^{8}$

${ }^{7}$ Vickie Kline, “A Word to Future Academic Librarians," in Expectations of Librarians In The 21st Century (United States: Karl Bridges, 2003), 74.

8 Ibid. 
Ini lah sebenarnya hakekat manusia. Selain sebagai makhluk inividu, manusia pada hakikatnya juga adalah makhluk sosial, dimana secara naluri ingin hidup berkelompok. Manifestasi dari hidup berkelompok ini adalah timbulnya organisasi atau lembaga atau institusi. Di dalam organisasi itu tiap anggota (individu) dapat memenuhi sebagian dari kebutuhannya antara lain menampakkan harga diri dan status sosialnya.

Manusia baik sebagai individu atau sosial, mempunyai berbagai macam kebutuhan material, kebendaan, maupun kebutuhan non material. Abraham maslow, mengklasifikasikan kebutuhan manusia itu sebagai berikut: ${ }^{9}$

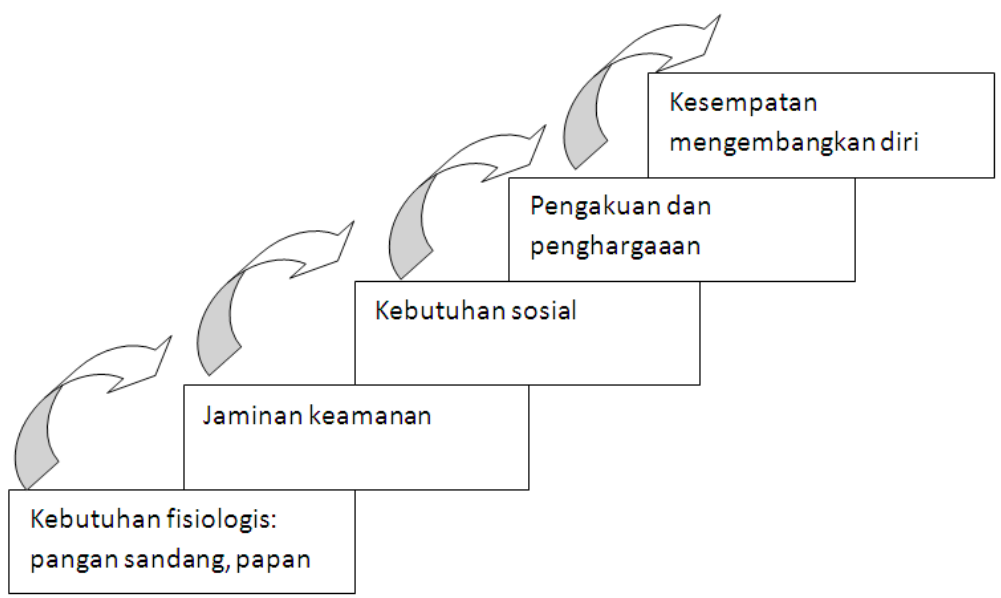

Gambar 1. Hirarki kebutuhan Maslow

Meskipun manusia memiliki kecenderungan berkelompok, bukan berarti manusia itu bersifat altruistic atau mengutamakan kebahagiaan orang lain. Artinya ada sisi ego yang sentrifugal yang menjadi pertimbangan pula pada diri manusia, dan kelompok sebagai kekautan sentripetal menjadi pertimbangan selanjutnya untuk mendukung dalam memenuhi kebutuhan.

Dewasa ini kompetensi semakin menjadi persyaratan yang harus dipenuhi oleh SDM perpustakaan. Masalah kompetensi

${ }^{9}$ Soekidjo Notoatmodjo, Permgembangan Sumber Daya Manusia, 3rd ed. (Jakarta: Rineka CIpta, 2003), hlm.6. 
menjadi penting karena kompetensi menawarkan suatu kerangka kerja yng efektif dan efisien dalam mendayagunakan sumbersumber daya yang terbatas. ${ }^{10}$ Sumber daya manusia atau tenaga kerja yang memiliki kompetensi memungkinkan setiap jenis pekerjaan dapat dilaksanakan dengan baik, tepat waktu, tepat sasaran, dan sebanding antara biaya dan hasil yang diperoleh. Kunci keberhasilan pelaksanaan strategi dan program pengembangan SDM terletak pada kemampuan pimpinan organisasi untuk mencari keseimbangan antara kedua kekuatan itu. ${ }^{11}$

Sumber daya manusia dalam sebuah organisasi menempati posisi yang strategis dalam menentukan keberhasilan suatu organisasi itu sendiri. Pencapaian tujuan sebagai bentuk kesuksesan ditentukan oleh SDM dalam konteks kompetensi dan kualitasnya. Begitu pula SDM di perpustakaan menjadi palang pintu kemajuan perpustakaan tempatnya bekerja. Perubahan lingkungan yang begitu cepat karena pengaruh teknologi dan informasi yang juga pesat berkembangnya, SDM seolah dituntut untuk cerdas dalam menganalisa perubahan, dampaknya terhadap organisasi, serta strategi yang digunakan dalam menghadapi tantangan yang sedemikian itu. Dari hal ini nampak sekali diperlukan ketangguhan, keuletan dan juga kompetensi yang mampu mengimbangi pergerakan kemajuani itu agar secara individu pun mampu bersaing dengan

Sejalan dengan persaingan yang semakin kompetitif yang diakibatkan karena perkembangan teknologi dan informasi ini, tidak dapat dihindarkan jika suatu organisasi atau institusi membutuhkan sumber daya manusia memiliki kompetensi yang relevan untuk dapat memberikan pelayanan yang baik bagi customernya. Ini artinya bahwa ada target lain selain produktivitas

${ }^{10}$ Departemen Pendidikan Nasional Republik Indonesia, Perpustakaan Perguruan Tinggi: buku pedoman, Edisi. ketiga (Jakarta, 2004).

11 S.P Siagian, Pengembangan Sumber Daya Insani, 2nd ed. (Jakarta: Gunung Agung, 1987), hlm. 17. 
dari masing-masing individu, yaitu pelayanan yang memuaskan dan memberikan nilai impressi yang baik bagi setiap pelanggan. ${ }^{12}$

Pengembangan SDM (dalam hal ini adalah pustakawan) berbasis pada kompetensi, perlu dilakukan untuk memberikan hasil yang sesuai dengan tujuan dan sasaran organisasi dengan standar kinerja yang telah ditetapkan. Kompetensi ini bisa menyangkut pengetahuan (cognition), sikap (afection), dan kreativitas (phsychomotoric) yang dimiliki. Kompetensi ini yang kemudian menjadi daya dukung pokok terhadap gerak lajunya organisasi.

Dalam rangka pengembangan ini, untuk dapat direalisasikan sebagai langkah nyata diperlukan suatu strategi atau cara-cara atau metode yang tepat, sehingga pengembangan ini tidak salah sasaran atau tidak sesuai dengan harapan. Strategi dalam Kamus Besar Bahasa Indonesia berarti rencana yang cermat mengenai kegiatan untuk mencapai sasaran khusus. ${ }^{13}$ Pengertian Strategi secara umum adalah teknik untuk mendapatkan kemenangan (victory) pencapaian tujuan (to achieve goals).

Pengembangan SDM perpustakaan yang bertujuan untuk meningkatkan kinerja dan hasil kerja pustakawan, dapat dilakukan melalui berbagai cara, misalnya: on the job training, konferensi dan seminar, mengikut sertakan diberbagai workshop dan pelatihan, pendidikan formal, rolling. ${ }^{14}$

\section{Tujuan Pengembangan Sumber Daya Manusia}

Tujuan pengembangan adalah agar individu, dalam situasi kerja, dapat memperoleh kemampuan untuk mengerjakan tugastugas atau pekerjaan tertentu secara baik, dan juga memiliki kompetensi yang lain disamping kompetensi standar pada tugas teknis kepustakawanan seperti: pengadaan, pengolahan, dan

12 Endah Setyowati, "Pengembangan SDM Berbasis Kompetensi: Solusi Untuk Meningkatkan Kinerja Organisasi," Diakses Melalui Www. Publik. Brawijaya. Ac. Id, 2003, hlm. 1.

${ }^{13}$ http://kbbi.web.id/strategi, akses tanggal 03 Januari 2016.

14 Pungki Purnomo, "Pembinaan Dan Pengembangan SDM Perpustakaan Pada Lembaga Pendidikan," AL-MAKTABAH 6, no. 1 (2004): 136, http://journal.uinjkt.ac.id/index.php/al-maktabah/article/view/1636. 
pelayanan perpustakaan. Sementara itu, Wexley dan Latham mengatakan bahwa program pengembangan memiliki satu atau lebih tujuan - tujuan berikut ini :

a. Meningkatkan kesadaran diri individu;

b. Meningkatkan keterampilan individu dalam satu bidang keahlian atau lebih; dan /atau

c. Meningkatkan motivasi individu untuk melaksanakan tugas atau pekerjaannya secara memuaskan. ${ }^{15}$

Melalui peningkatan kemampuan dan kinerja individu dan kelompok, program pengembangan ini pada gilirannya diharapkan dapat meningkatkan kinerja organisasi. Pada dasarnya, tujuan utama pengembangan kompetensi sumber daya manusia adalah ingin meningkatkan produktivitas kerja pada semua tingkat organisasi. Kegiatan pelatihan, misalnya sebagai salah satu meotode pengembangan kompetensi sering kali terbukti mampu meningkatkan keterampilan dan motivasi. Hal ini pada gilirannya, akan mengarah pada produktivitas yang lebih tinggi dan pada akhirnya dapat meningkatkan profitabilitas sebuah organisasi.

Tujuan lain pengembangan kompetensi sumber daya manusia ini adalah mencegah keusangan keterampilan pada semua tingkat organisasi. Perkembangan ilmu pengetahuan dan teknologi serta kebutuhan organisasi yang berubah, pada rentang waktu tertentu, keterampilan yang dimiliki karyawan sering menjadi usang atau tidak bisa digunakan lagi. Setiap organisasi berkewajiban membantu para pekerjanya untuk selalu meningkatkan keterampilan berdasarkan minat dan bakat mereka, selain untuk memenuhi kebutuhan organisasi.

Di samping itu, pengembangan sumber daya manusia ditujukan untuk mempersiapkan pekerja sehingga ke depan dapat menjalankan tugas atau pekerjaan yang lebih tinggi jenjangnya.

${ }^{15}$ Niarsyah Liany, "Pengaruh Pelatihan Terhadap Prestasi Kerja Pada PT. Bank Prekreditan Rakyat Nusantara Bona Pasogit (BPR NBP) 30 Ciwidey" (Fakultas Ekonomi Dan Bisnis (UNISBA), 2015), 14, http://repository.unisba. ac.id/handle/123456789/710. 
Dengan demikian, biaya yang dikeluarkan untuk mengembangan sumber daya manusia seharusnya dipandang sebagia sebuah investasi dalam bidang sumber daya manusia.

\section{Menuju kompetensi kelas dunia}

Kompetensi didefinisikan sebagai underlying characteristic's of an individual which is causally related to criterion-referenced effective and or superior performance in a job or situation. Atau karakterisitik yang mendasari seseorang dan berkaitan dengan efektivitas kinerja dalam pekerjaannya. ${ }^{16}$ Dubois $(1989,86)$ menyebutkan bahwa kompetensi adalah edge or skill that is critical for producing key outputs, atau dengan kata lain keterampilan itu merupakan kunci untuk menentukan keberhasilan. Da juga mencacatat bahwa orang-orang yang memiliki pengetahuan dapat memperceatkerja merupakan definisi dariperpustakaan. Sementara itu George Klemp (1980) mendefinisikan bahwa kompetensi merupakan pekerjaan sebagai bagian dari karakteristik yang diwuiudkan sebagai karakteristik persorangan yang menghasilkan efektivitas yang kerja. ${ }^{17}$ Pengertian lainnya dikemukakan oleh Dubois yang menjelaskan bahwa kompetensi menyangkut ke dalam lima hal, yaitu motivasi (motivation), sifat (traits), konsep diri (self concept), pengetahuan (knowledge) dan keterampilan (skill). 18 Mulyasa pun mendefinisikan kompetensi sebagai perpaduan dari pengetahuan, keterampilan, nilai dan sikap yang direfleksikan dalam kebiasaan berfikir dan bertindak. ${ }^{19}$

Beberapa istilah di atas menyangkut pengertian kompetensi itu sendiri, masih memerlukan interpretasi. Hasil interpretasi dari istilah kompetensi lebih condong pada dua hal, yaitu pertama,

${ }^{16}$ Alain Mitrani, Murray M. Dalziel, and David Fitt, Competency Based Human Resource Management: Value-Driven Strategies for Recruitment, Development and Reward (Kogan Page, 1992).

17 Ibid., 5.

18 David D. Dubois, ed., Competency-Based Human Resource Management, 1st ed (Palo Alto, Calif: Davies-Black Pub, 2004), hlm. 18.

${ }^{19}$ E. Mulyasa, Kurikulum Berbasisi Kompetensi: Konsep, Karakteristik, Dan Implementasi, 3rd ed. (Bandung: Rodsa Karya, 2003), hlm. 37. 
kompetensi sebagai karakteristik dasar yang mengarah pada kemampuan meningkatkan kinerja, dan kedua, kompetensi sebagai alat yang digunakan oleh para pekerja untuk mempredikisi tingkat kinerjanya. Competence is the ability to do the tasks required in a job, The training sessions are intended to increase staff competence. ${ }^{20}$ Secara sederhana kompetensi ni diartikan suatu kemampuan untuk mengerjakan tugas-tugas dalam pekerjaannya. Kompetensi staff ini merupakan seperangkat tanggungjawab atau tugas yang menjadi bagian dari pekerjaan dengan standard-standard yang telah ditentukan untuk mencapai sebuah tujuan.

Dubois menerangkan pula bahwa competence consist of knowledge, skills, and attitude to include motivation levels, personality traits, awareness of bodies of knowledge, or any of those variables that may be developed and which distinguish exemplary from fully successful performers. ${ }^{21} \quad$ Kompetensi ini suatu komponen yang mengadung unsur pengetahuan, sikap, motivasi, kepribadian, dan keterampilan dan yang paling penting adalah bentuk kepedulian terhadap pengetahuan sehingga ini menjadi pembeda dengan orang lain. Sementara itu pada ranah teknologi dan informasi itu sendiri menuntut adanya orang yang mampu mengelola bidang ini jika pustakawan dan pekerja informasi bersatu maka bejeke cara yang efektif. ${ }^{22}$

Menjadi sekelindan pula jika disandingkan dengan sumber lain yang merumuskan kompetensi dan sekaligus membedakannya dalam dua jenis kompetensi, yaitu: Kesatu, kompetensi profesional, yaitu yang terkait dengan pengetahuan pustakawan di bidang sumber-sumber informasi, teknologi, manajemen dan penelitian, dan kemampuan menggunakan pengetahuan tersebut sebagai

${ }^{20}$ A Ivanovic and P. H Collin, Dictionary of Human Resources and Personnel Management (London: A \& C Black, 2006), hlm. 54, http://search. ebscohost.com/login.aspx? direct $=$ true $\&$ scope $=$ site $\& \mathrm{db}=$ nlebk $\& \mathrm{db}=$ nlabk $\& \mathrm{~A}$ $\mathrm{N}=217320$.

21 Dubois, Competency-Based Human Resource Management, hlm. 131.

22 Jordan and Libia, Staff Management in library and Information work, vol. 220_04_2016 (Ashgate foundation, 2005), ahgate. 
dasar untuk menyediakan layanan perpustakaan dan informasi. Kedua, kompetensi individu yang menggambarkan satu kesatuan keterampilan, perilaku dan nilai yang dimiliki pustakawan agar dapat bekerja secara efektif, menjadi komunikator yang baik, selalu meningkatkan pengetahuan, dapat memperlihatkan nilai lebihnya, serta dapat bertahan terhadap perubahan dan perkembangan dalam dunia kerjanya. ${ }^{23}$

Dengan demikian kompetensi merupakan pengetahuan, keterampilan dan nilai-nilai yang telah menjadi cara berpikir dan bertindak seseorang dalam menghadapi permasalahan. Oleh sebab itu individu yang memiliki kompetensi dapat diukur dari kemampuannya untuk menjadi pelaku kinerja unggulan atau pelaku kinerja efektif. Kembalikekonsepkompetensi yang membawaistilah motif, karakter, dan konsep diri, maka aspek kompetensi demikian itu dapat meramalkan suatu perilaku teretentu yang pada akhirnya muncul kinerja yang dapat digambarkan sebagai berikut:

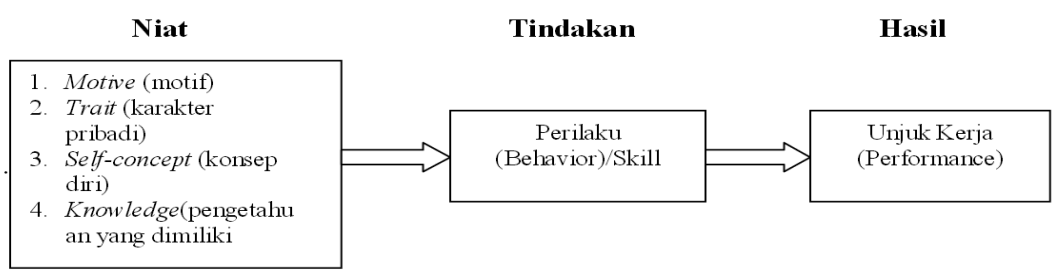

Gambar 2 Komponen kompetensi

Kompetensi sumber daya manusia dalam sebuah organisasi menjadi penting adanya. Karenanya perlu perhatian yang lebih untuk dapat menjawab kebutuhan organisasi. Perkembangan teknologi informasi sejalan pula dengan meningkatknya kebutuhan manusia yang berposisi sebagai aktor inti dalam perkembangan. Pengembangan SDM memungkinkan tidak hanya dalam satu aspek saja, melainkan multi aspek sesuai dengan tuntutan kebutuhan institusinya.

${ }^{23}$ Indonesia, Perpustakaan Perguruan Tinggi: buku pedoman, hlm. 27. 
Di era globalisasi ini terjadi pergeseran paradigm persaingan bagi perguruan tinggi, dari awalnya persaingan antar perguruan tinggi dalam suatu Negara menjadi persaingan antar perguruan tinggi antar negara. Hal ini antara lain merupakan implikasi dari globalisasi dengan perdagangan bebas termasuk jasa pendidikan, sebagai motor penggeraknya.

Pun dengan Perpustakaan Perguruan tinggi harus dapat memainkan peran nya sebagai salah satu instrumen penting untuk mendorong daya saing bangsa di level nasional dan internasional. Perpustakaan perguruan tinggi di negara ini harus. didorong untuk memiliki kualitas internasional. Sampai tahun 2008, sekitar dua ratus perguruan tinggi terbaik masih didominasi Jepang dan Cina.

Banyak universitas di Indonesia mendambakan ingin menjadi salah satu World Class University, sebagai bukti berkualitas dan memiliki reputasi. Selama ini, perguruan tinggi kurang memperhatikan tata kelola perpustakaan dan aspeknya. perpustakaan sudah saatnya diarahkan agar lebih berkualitas agar bisa mendukung perguruan tingginya dalam level World Class University.

\section{Bagaimana World Class Library?}

Perpustakaan sebagai penyangga keilmuwan perguruan tinggi memiliki andil besar dalam mewujudkan cita-cita akademis lembaganya. Di masa kini, perpustakaan harus sudah mulai keluar dari paradigm lama yang memberikan kesan bahwa perpustakaan itu hanya sekedar tempat buku saja, perpustakaan hanya jajaran buku di rak yang disusun rapi berdasarkan klasifikasi tertentu. Penyadaran masyarakarakat bahwa perpustakaan kini lebih pada sekumpulan ide, tempat berinteraksi antar orang, tempat berbagi informasi dan pengetahuan, tempat eksplorasi keinginan akademis, dan lain-lain, belum bisa diterima secara menyeluruh oleh masyarakat yang lebih luas.

Perpustakaan masa kini adalah perpustakaan yang tidak berlomba menumpuk koleksi. Perpustakaan era sekarang adalah 
perpustakaan yang secara apik mendekati pemustaka dengan berbagai "seni" yang memikat. Pustakawan yang berperan di sana juga lebih luwes, fleksibel dan adapatif.

Ada sejumlah peran yang harus dimainkan perpustakaan ketika world class universitymenuntut persyaratannya. sebagaimana terlihat pada bagan di bawah ini:

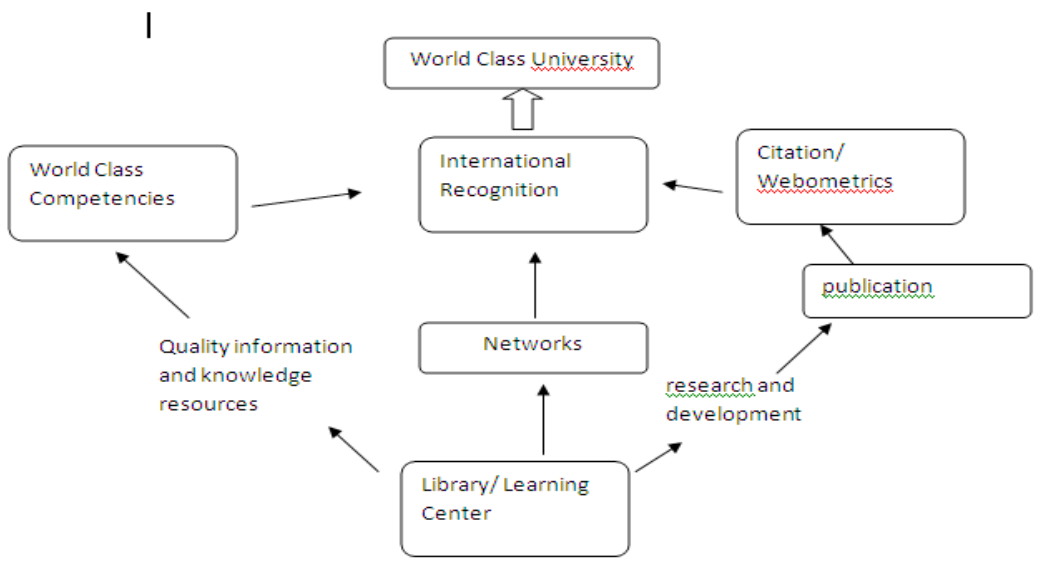

Gambar 3. komponen library menuju WCU

Persyaratan itu bertumpu pada kreativitas pustakawan, yang tentunya berdasar pada kompetensi yang dimilikinya. Maka peran pustakawan adalah mengawal perpustakaan atau tempat learning center ini untuk bisa melakukan kegiatan berikut:

a. Research and development college

Adalah fungsi perpustakaan sebagai pusat penelitian dan pengembangan. Dimaksudkan disini bahwa perpustakaan adalah sebagai laboratoriumnya para ilmuwan untuk menemukan literature-literatur pendukung penelitiannya dan mengembangkan objek penelitiannya sehingga memungkinkan hasil penelitiannya itu adalah alat pengambil kebijakan pengembangan lembaga secara menyeluruh.

Perpustakaan adalah salah satu unsur penunjang menuju research college. Diberbagai universitas terkemuka didunia, terdapat perpustakaan yang mendukung. Sebagian perpustakaan tersebut 
sudah menggunakan teknologi informasi untuk mempermudah. Hal ini makin menambah kemudahan bagi penggunanya (user). Diharapakan jika dengan kondisi seperti itu, tingkat penelitian dan gairah perkembangan ilmu pengetahuan terus berkembang. ${ }^{24}$

Membangun perpustakaan berkualitas adalah salah satu syarat menuju research college. Dalam konsep research college , perpustakaan tidak hanya menjadi fasilitas pelengkap. Namun lebih dari itu, perpustakaan menjadi pendorong bagi civitas kademika untuk melakukan penelitian (research). Perpustakaan adalah media untuk melakukan 'transfer informasi' kepada civitas akademika. Dengan demikian, civitas akademka makin terasah kemampuan dan pengetahuannya untuk melakukan penelitian.

Sebagai contoh Harvard memiliki reputasi sebagai salah satu universitas riset paling tersohor. Banyak penelitiannya dari berbagai disiplin ilmu telah dipublikasikan dan dipraktekkan. Salah satu upaya paling sederhana yang dilakukan Harvard untuk terus mengembangkan risetnya adalah dengan melibatkan mahasiswamahasiswa S1 dalam berbagai penelitian yang dipimpin langsung oleh seorang profesor maupun studi independen. ${ }^{25}$

Perpustakaan Universitas menjadi bagian dari penelitian ini. Perpustakaan-perpustakaan tersebut berkolaborasi dengan koleksi digital, teknologi informasi, penyimpanan tingkat tinggi, dan pelestarian informasi. Perpustakaan Harvard tersebar di setiap fakultas dan disiplin ilmu, selain juga pusat-pusat riset mereka. Setiap perpustakaan ini memiliki situs tersendiri yang bisa diakses online dan terintegrasi ke dalam situs utama mereka. Situs perpustakaan ini lengkap dan komprehensif dengan layanan elektronik yang mencakup materi yang diperlukan, akses mudah

24 Arip Muttaqien, Membangun Perpustakaan Berbasis Konsep Knowledge Management: Transformasi Menuju Research College Dan Perguruan Tinggi Berkualitas Internasional (Maret, 2006), 6, http://152.118.24.150/files/ Arip_Muttaqien.pdf.

${ }^{25}$ Rizki Amalia Affiat, Perpustakaan Harvard Sebagai Contoh Kemajuan Universitas Berbasis Riset Dan Bertaraf Internasional: Sebuah Refleksi Bagi UI (Maret, 2006), 9, http://152.118.24.150/files/Rizki_Amalia_Affiat.pdf. 
mendapatkan materi, hingga semua fasilitas dan kegiatan yang dilakukan oleh perpustakaan. Melalui kesatuan jaringan online, perpustakaan memiliki link langsung ke setiap fakultas dan tempat riset. $^{26}$

\section{b. Publication}

Publikasi merupakan satu kekuatan yang diukur untuk menentukan citra lembaga. Sesungguhnya ini tugas lembaga secara makro. Namun demikian ada peran yang perlu diambil perpustakaan dari sudut publikasi ini, yaitu mengelola publikasi yang dihasilkan lembaga sebagai institutional repository dan dipublikasikan melalui perpustakaan. hal ini terkait dengan fungsi perpustakaan sebagai fungsi simpan-saji karya.

Surat Edaran no. 59 Tahun 2011 tentang publikasi ilmiah menguatkan niat pemangku pendidikan untuk memberikan sumbangan besar terhadap ilmu pengetahuan, bahwa setiap karya ilmiah yang dihasilkan oleh sivitas akademik perguruan tinggi disarankan untuk dipublikasikan.

Merujuk pula pada Peraturan Menteri Pendayagunaan Aparatur Negara dan Reformasi Birokrasi (PAN RB), Nomor 17 Tahun 2013, dan Peraturan Menteri Pendidikan dan Kebudayaan Nomor 92 Tahun 2014, kenaikan jenjang jabatan akademik dosen mewajibkan untuk publikasi pada jurnal ilmiah nasional terakreditasi dan jurnal internasional bereputasi di bidangnya. Disinyalir dengan kebijakan ini diharapakan dapat memberikan suatu arah agar publikasi ilmiah jabatan fungsional Dosen di Indonesia terus meningkat.

Adapun tujuan dari publikasi ini adalah mensosialisasikan hasil temuan dari kajian atau penelitian berdasarkan evidence (bukti/kebenaran/fakta/data) di lapangan baik di tingkat lokal, nasional, regional dan internasional . Banyak sekali fakta hasil kajian dan penelitian yang sebetulnya sangat penting dan menarik untuk diakses dan dijadikan bahan yang sangat penting untuk pengambilan keputusan, tetapi sulit untuk diperoleh/diakses/

\footnotetext{
${ }^{26}$ Ibid., hlm. 10.
} 
dijangkau oleh pengambil kebijakan atau pihak pengguna lainnya. Hal ini disebabkan karena hasil kajian/penelitian para peneliti, dosen, mahasiswa tidak dipublikasikan secara luas. ${ }^{27}$

Jurnal digital (e-journal) melalui Open Journal System (OJS) menjadi sarana yang sangat baik untuk mempublikasikan hasil penelitian pada lingkup yang lebih luas. Perpustakaan dengan e-print dan sejenisnya bisa menangkap ini sebagai kekuatan koleksi institustional repository. sehingga hal ini ke depan diharapkan dapat meningkatkan reputasi yang baik untuk referensi dari para penulis dan kasus dari Indonesia untuk di dalam pengembangan ilmu pengetahuan.

\section{c. Citation/ webometrics}

Peran lain perpustakaan adalah mengawal visibilitas lembaga melalui karya-karya anak bangsa yang dihasilkan dari sivitas akademik setempat di ranah publikasi. visibilitas lembaga dan sejauh mana situs lembaga di akses oleh masyarakat adalah salah satu ukuran penilaian webometrics yang merilis tingkat popularitas lembaga secara internasional maupun nasional.

Sebarapa banyak jumlah karya dosen yang disitir oleh pemustaka juga sebagai indikator kemapanan karya ilmiah yang dihasilkan. selain mempengaruhi reputasi lembaga, juga berpangaruh pula terhadap reputasi individu penulis yang karyanya di sitir oleh pemustaka dari mana saja dia berasal.

Sebagai contoh Publikasi ilmiah dalam jurnal bereputasi internasional berperan sebagai media aktualisasi diri para akademisi dan peneliti dalam pengembangan ilmu pengetahuan secara internasional. Lebih jauh lagi, jumlah publikasi internasional juga berperan meningkatkan harga diri suatu negara dalam bentuk diplomasi mutu pendidikan dan ilmu pengetahuan.

Negara-negara yang memiliki mutu pendidikan dan iptek yang bagus cenderung memiliki jumlah publikasi internasional

27 Septiana Dwiputrianti, "Pentingnya Publikasi Dan Akses Hasil Penelitian," accessed May 14, 2016, http://stialanbandung.ac.id/index. php?option=com_content $\&$ view=article\&id=735:pentingnya-publikasi-danakses-hasil-penelitian-\&catid=12:artikel\&Itemid=85. 
yang tinggi. Situs olahan pemeringkatan publikasi ilmiah SCIMAGO Lab. (www.scimagojr.com) melaporkan jumlah publikasi ilmiah dari tahun 1996-2013 berdasarkan data dari SCOPUS. Portal tersebut memeringkat hasil publikasi 239 negara. Dari portal SCIMAGO diketahui jika Indonesia berada pada urutan ke-61 dengan jumlah publikasi sebanyak 25.481. Indonesia kalah jauh dari negara tetangga ASEAN seperti Malaysia yang menempati urutan ke-37 dengan jumlah publikasi karya ilmiah 125.084, Singapura yang berada di peringkat ke-32 dengan jumlah publikasi 171.037, dan Thailand pada peringkat ke-43 dengan jumlah publikasi 95.690.

Negara ASEAN yang di bawah Indonesia adalah Vietnam dengan peringkat 66 yang memiliki jumlah publikasi sebanyak 20.460. Dari situs SCIMAGO tersebut juga bisa dilihat tiga negara paling produktif menerbitkan karya-karya ilmiah, yaitu untuk peringat ke-1 diduduki oleh Amerika Serikat dengan jumlah publikasi karya ilmiah 7.846.972, peringkat ke-2 adalah Tiongkok (China) dengan jumlah publikasi3.129.719, dan peringkatke-3 yakni Inggris dengan jumlah publikasi 2.141.375. ${ }^{28}$

Dari rangking publikasi internasional Indonesia di atas, bisa disimpulkan jika jumlah publikasi bereputasi internasional Indonesia cukup memprihatinkan. Hal ini tentu menarik untuk melihat akar permasalahan yang menyebabkan Indonesia memiliki rangking publikasi ilmiah internasional lebih rendah, termasuk dari beberapa negara ASEAN seperti Malaysia, Singapura, dan Thailand.

Maka untuk mewujudkan perpustakaan yang WCU tadi, perlu passion dari pustakawan untuk secara menjiwai peran dan fungsi perpustakaan di era sekarang ini. Pustakawan tidak boleh lagi terperangkap pada rutinitas yang membelenggu kreativitas, ia harus keluar dari jebakan rutinitas itu menjadi lebih

28 Sindo, "Rangking Publikasi Ilmiah Internasional Indonesia," SINDOnews.com, April 13, 2015, http://nasional.sindonews.com/ $\mathrm{read} / 988644 / 162 /$ rangking-publikasi-ilmiah-internasional-indonesia1428903924. 
kreatif, emancipatif, responsif, elegan dan yang penting adalah menumbukah jiwa nasionalisme.

\section{d. Networks}

Membentuk jaringan perpustakaan dan jaringan informasi penting dilakukan oleh perpustakaan sebagai upaya memberdayakan dan mempromosikan perpustakaan itu sendiri. kekuatan perpustakaan yang dimiliki dapat diketahui oleh masyarakat secara luas adalah sebuah keuntungan. dengan berjejaring dapat saling berbagi informasi dan pengetahuan dan dapat saling melengkapi kekurangan.

Dalam kemitraan, seluruh elemen mendapatkan apa yang menjadi kebutuhannya. Sinergi antar elemen menjadi kunci dalam memainkan perannya masing-masing. Bangunan kemitraan harus didasarkan padahal-hal berikut: kesamaan perhatian (common interest) atau kepentingan, adanya sikap saling mempercayai dan saling menghormati, tujuan yang jelas dan terukur, dan kesediaan untuk berkorban baik, waktu, tenaga, maupun sumber daya yang lain. Secara umum, prinsip-prinsip kemitraan adalah persamaan atau equality, keterbukaan atau transparancy dan saling menguntungkan atau mutual benefit.

\section{e. Quality of the information and knowledge resources}

Perpustakaan lagi-lagi menjadi tumpuan besar bagi perguruan tinggi untuk menyajikan dan mengelola sumber-sumber informasi yang berkualitas. Dalam arti yang lebih khusus adalah kerelevanan antara kebutuhan pemustakan dengan informasi yang disediakan perpustakaan.

Informasi dan pengetahuan di perpustakaan disimbolkan dalam koleksi yang dikelolanya. Buku, e-book, journal, e-journal, majalah, e-magazine dan koleksi yang lain sesungguhnya adalah sekumpulan informasi dan pengetahuan.

\section{Simpulan}

Sebagai penutup dapat disimpulkan disini bahwa pertama, untuk menuju perpustakaan yang berkualitas yang dicita-citakan 
menuju perpustakaan yang berlevel world classs university, perlu meningkatkan kompetensi SDM perpustakaan (pustakawan).

Kedua, perlu penyadaran bagi seluruah komponen perguruan tinggi terhadap peran vital perpustakaan di perguruan tinggi sebagai center of knowledge; Ketiga, ada beberapa kualifikasi yang perlu diupayakan perpustakaan untuk disupport dan diseriusi, yaitu: Perpustakaan sebagai Research and development college, Perpustakaan sebagai ranah Publication, Perpustakaan sebagai center of control terhadap Citation/ webometrics, Perpustakaan perlu membentuk Networks, dan Perpustakaan perlu mengelola Quality of the information and knowledge resources.

Demikian makalah ini semoga bermanfaat bagi semua pembaca. salam hangat dan salam sinergi. 


\section{DAFTAR PUSTAKA}

Affiat, Rizki Amalia. Perpustakaan Harvard Sebagai Contoh Kemajuan Universitas Berbasis Riset Dan Bertaraf Internasional: Sebuah Refleksi Bagi UI. Maret, 2006. http://152.118.24.150/files/Rizki_Amalia_Affiat.pdf.

Altbach, Philip. "The Costs and Benefits of World-Class Universities." International Higher Education, no. 33 (2015). http://ejournals.bc.edu/ojs/index.php/ihe/article/ viewFile/7381/6578.

Azra, Azyumardi. "World Class University." Republika. 20 April, 2006.

Dubois, David D., ed. Competency-Based Human Resource Management. 1st ed. Palo Alto, Calif: Davies-Black Pub, 2004.

Dwiputrianti, Septiana. "Pentingnya Publikasi Dan Akses Hasil Penelitian." Accessed May 14, 2016. http://stialanbandung. ac.id/index.php?option=com_content\&view=article\&id =735:pentingnya-publikasi-dan-akses-hasil-penelitian\&catid=12:artikel\&Itemid $=85$.

Haryanti, Enny. "Strategi Pengembangan Kelembagaan Perguruan Tinggi Menuju World Classs University," n.d. Accessed May 12, 2016.

Hayward, Fred M. "Strategic Planning for Higher Education in Developing Countries: Challenges and Lessons." Planning for Higher Education 36, no. 3 (2008): 5-21.

Indonesia, Departemen Pendidikan Nasional Republik. Perpustakaan Perguruan Tinggi: buku pedoman. Edisi. ketiga. Jakarta, 2004.

Ivanovic, A, and P. H Collin. Dictionary of Human Resources and Personnel Management. London: A \& C Black, 2006. http:// search.ebscohost.com/login.aspx?direct=true\&scope $=$ site $\& \mathrm{db}=$ nlebk \&db=nlabk\&AN=217320.

Kline, Vickie. "A Word to Future Academic Librarians." In Expectations of Librarians In The 21st Century, 232. United States: Karl Bridges, 2003. 
Liany, Niarsyah. "Pengaruh Pelatihan Terhadap Prestasi Kerja Pada PT. Bank Prekreditan Rakyat Nusantara Bona Pasogit (BPR NBP) 30 Ciwidey." Fakultas Ekonomi Dan Bisnis (UNISBA), 2015. http://repository.unisba.ac.id/ handle/123456789/710.

Libia, Jordan and. Staff Management in library and Information work. Vol.220_04_2016. 4hth vols. Ashgate foundation, 2005.

Mitrani, Alain, Murray M. Dalziel, and David Fitt. Competency Based Human Resource Management: Value-Driven Strategies for Recruitment, Development and Reward. Kogan Page, 1992.

Mulyasa, E. Kurikulum Berbasisi Kompetensi: Konsep, Karakteristik, Dan Implementasi. 3rd ed. Bandung: Rodsa Karya, 2003.

Muttaqien, Arip. Membangun Perpustakaan Berbasis Konsep Knowledge Management: Transformasi Menuju Research College Dan Perguruan Tinggi Berkualitas Internasional. Maret, 2006. http://152.118.24.150/files/Arip_ Muttaqien. pdf.

Notoatmodjo, Soekidjo. Permgembangan Sumber Daya Manusia. 3rd ed. Jakarta: Rineka CIpta, 2003.

Purnomo, Pungki. "Pembinaan Dan Pengembangan SDM Perpustakaan Pada Lembaga Pendidikan." AL-MAKTABAH 6, no. 1 (2004). http://journal.uinjkt.ac.id/index.php/almaktabah/article/view/1636.

Rubin, Richard. Foundations of Library and Information Science. Fourth edition. Chicago: ALA Neal-Schuman, an imprint of the American Library Association, 2016.

Setyowati, Endah. "Pengembangan SDM Berbasis Kompetensi: Solusi Untuk Meningkatkan Kinerja Organisasi." Diakses Melalui Www. Publik. Brawijaya. Ac. Id, 2003.

Siagian, S.P. Pengembangan Sumber Daya Insani. 2nd ed. Jakarta: Gunung Agung, 1987.

Sindo. "Rangking Publikasi Ilmiah Internasional Indonesia." SINDOnews.com, April 13, 2015. http://nasional. sindonews.com/read/988644/162/rangking-publikasiilmiah-internasional-indonesia-1428903924. 